tion of the Conflict" and "Summary and Synthesis," the author again returns to the value of the symbol as the "energy carrier from one level to the next higher level in this process" of development.

Throughout there is a wealth of illustrations drawn from pathological and child psychology, as well as from that of primitive man, in the explanation of the various technical terms. The book is one of the first attempts to gather together and systematize the various principles of psychoanalysis and as such is invaluable as an introduction and a summary in this field.

\title{
E. Bowman.
}

Daniet Starch Advertising. Its Principles, Practice, and Technique. Scott, Foresman and Company, Chicago, 1914, pp. 281

As appears from the preface, this book is intended to serve "as a textbook for students and as an introductory handbook for business men" The author has endeavored to combine the practical and the theoretical aspects of the subject in such a way that the practical experiences of business houses, which are quoted at length, may illustrate the underlying principles, and that the discussion of principles. may illuminate the practical results of business.

Advertising specialists all over the country agree that Professor Starch has contributed the best book on advertising thus far, considering its simplicity, accuracy and helpfulness.

The contents cover the following phases of advertising: The place of advertising in the business world; problems of advertising; attracting attention; reaching the people; display type--its attention-value and use, the size of advertisements; emphasis and unity in advertisements, avoidance of counter-attractions; contrast, the use of colors and novel features, borders, eye-movement and attention; mediums,magazines, newspapers, street railway cards; trade names and trade marks; headlines; illustrations; repetiton and cumulative effect; type and legibility; artistic elements in advertisements; arrangement, balance, and harmony; argumentative advertisements, suggestive advertisements; testing the strength of advertisements; the ethics of advertising

The organization of the material is excellent The changes in the methods and ideals of advertising are taken up and lllustrated by the type of copy used by the leading firms. The results of investigations by various firms to determine the efficiency of the advertisements are given in detail Professor Starch presents the results of laboratory experiments, and the relation between these experiments and that "of the advertisement in operation is always clearly shown" But the function of an advertisement is to attract attention, to stimulate interest, and to secure a response, and the psychological principles which underlie the construction of the advertisement itself, are taken up in detail. It should be noted that psychological technicalities are avoided so that the material is easily understood by the average reader.

It is estumated that in the United States eight hundred million dollars are spent annually for the purpose of advertising, and the printed space consumed would cover two thousand square miles A full-page advertisement in the back issue of a leading magazine for women, for only one issue, cost ten thousand dollars. The problem of the advertiser is a large one, and this book should be looked upon as a primer of the science and practice of advertising.

Teachers of advertising will welcome this text-book for it presents fundamental principles in such a concrete form that the students can 
readily absorb them Professor Starch is the first writer to produce a text-book on advertising that anywhere near fills the need. This volume should be read by every one interested in any phase of advertising.

JoHn A. Stevenson.

The following books and pamphlets have been received..$^{x}$

Ellsworth Huntington. Civilization and Clmate. Yale University Press, New Haven, 1915.

Indiana University Studies, No 32 Studies in Anthmetic. Edtted by Melvin E Haggerty, Vol 3, September, 1916 No 34 The Ability to Read. Its Measurement and Some Factors Conditnonng it. Edited by MELVIN E HAGGERTY, Vol 4, January, IgI7

Robert M. Yerkes and Harold E Burt. The Relation of Pont-Scale Meastrements of Intelligence to Educational Performance in College Students. Reprinted from School and Society, Vol 5. No 123, pp 535-540. May, 1917.

Harold E. BURT. Audtory Illusions of Movement - A Preliminary Study. Reprinted from Journal of Experinental Psychology, Vol 2, No. I, February, I9I7

J E Wallace Wallin. The Feebleminded in the State of Missouri. Reprinted from The Psychological Chnic, Vol. II, No. 2, April, 1917.

- A Program for the State Care of the Fecbleminded and Epileptic. Reprinted from School and Soctety, Vol 4, No 98, November, 19I6

$$
\text { The Problem of the Fecblemnded in its Educational and }
$$
Social Bearings. Reprinted from School and Society', Vol. 2. No 30, July, Igr 5 .

${ }^{1}$ Mention here does not preclude further comment 